\title{
The Development of Negotiation Text Oriented to Higher Order Think- ing Skills (HOTS) for Teaching Material with the Context of Life Skills in the Business and Industrial World
}

\author{
${ }^{(1)}$ Sri Utami, ${ }^{(2)}$ Lailiyatus Sa'diyah \\ Universitas Nahdlatul Ulama Blitar, Indonesia \\ E-mail: (1) utami3215@gmail.com, ${ }^{(2)}$ lailiyatus_Sadiyah@yahoo.com
}

Received: 30 July 2020; Revised: 23 October 2020; Accepted: 25 October 2020

\begin{abstract}
Abstrack
Based on the needs of soft skills for Vocational High School (SMK) students, the content of this negotiation text for teaching material is prioritized to meet the needs of the Business World-Industrial World (DU-DI) through problem solving, which is designed to take advantage of issues in the context of DU-DI. This research and development is an innovative negotiation text teaching material that integrates the context of life skills in DU-DI in SMK students by orienting Higher Order Thinking Skills (HOTS). Specifically, this study aims to produce a negotiation text teaching material product and describe its feasibility, including the level of validity, practicality, and attractiveness of negotiation text for the teaching material product oriented to HOTS in the context of life skills in DU-DI for SMK. The development model used Borg \& Gall, including five stages. The product testing was carried out to determine the product's feasibility, consisting of expert validation, teachers, and smallscale field trials carried out on students. The average percentage of expert validation is $90.67 \%$, field testing on Indonesian language teachers is $89.8 \%$, and field testing on students is $95 \%$. These data showed that the textbook about negotiation text in the context of life skills was categorized as the very feasible textbook to be implemented in learning negotiation text in SMK.
\end{abstract}

Keywords: Negotiation, HOTS, life skills, DU-DI

\section{INTRODUCTION}

Excellent human resources can be seen from the productivity measures. Indonesia has pursued various programs to produce productive human resources. The program that has been implemented by the Indonesian government to create competitive Indonesians is through the revitalization of vocational education. This program seeks to align the SMK curriculum with the needs of the DU-DI. The quality of human resources is the key for Indonesia in preparing for industrial competition. This motivates vocational schools to take part in industrial progress in Indonesia.

The profile of SMK graduates was de- scribed as a profile of a person with character, dynamic adaptability, and the ability to apply basic daily skills. With this profile, SMK graduates can solve complex problems at DU-DI. This has also been programmed through Nawacita, stated in the National Medium Term Development Plan (RPJMN) of 2015-2019, to improve the quality of Indonesian human life, people's productivity, and competitiveness in the international market. When core skills are gone in 2020 , the younger generation of SMK is ready to pursue careers and develop the Indonesian economy through 4C (critical skills, creativity, collaboration, communication).

Communication is a feature of a person's 
skill in 4.0 because this ability can overcome Indonesia's problems to meet labor needs, create jobs, and be optimistic as a productive nation. SMK students are prospective business actors to run their businesses by interacting and needing each other to cooperate. That interaction means is communication. Communication skills as soft skills of vocational students can be strengthened through the negotiation learning needed by DUDI in associating relationships, information on goods, and services with good and optimistic negotiation stages to reach an agreement with mutual benefits. When students move in the dynamics of business and industry, they must seek opportunities transformed through cooperation, sales, and or services. So, negotiation skills are needed when interacting with business partners or users of their products or services through strategic efforts to reach an agreement with other people. Ayuningtyas (2018) has developed a negotiation text teaching material in an interactive $C D$ as an assistive medium for understanding negotiation texts. This research emphasizes the integration of the context of skills in the world of work-industry.

Based on the needs of soft skills on vocational students, the content of this negotiation text for teaching material is prioritized to meet the needs of DU-DI through problem solving, which is designed to take advantage of issues in the context of DU-DI. This aims to introduce and equip vocational students in the complex dynamics of the industrial era 4.0. Besides, this learning is oriented to Higher Order Thinking Skills (HOTS) in the form of three levels from the revised Bloom Taxonomy, in the form of analyzing, evaluating, and creating.

Joachim Funke (2018: 46) states problem solving is a goal-oriented and high-level cognitive process. This implies that, for a problem to be solved, many elementary cognitive operations like attention, perception, learning, memory use, etc. need to be coordinated effectively. One of the problem solving models is the Polya model. According to Polya, there are four learning steps for problem solving, including (1) understanding the problem, (2) determining the problem solving strategy plan, (3) completing the problem solving strategy, and (4) checking the answers again. This learning is begun with giving problems, then students practice under- standing, strategizing, and implementing strategies to draw conclusions. The teacher guides students in each problem solving step by giving questions that lead to concepts (Komariah, 2011: 182). SMK students must be observant and careful in seeing real-world problems presented by business or industry actors.

Because problem solving is goal-oriented and high-order thinking, then the need for this negotiation learning is focused on HOTS. This is supported by Tia Ristiasari who states that the problem solving learning model can develop students' critical thinking skills. SMK students have life skills by learning in vocational schools under their fields of learning context by applying higher-level thinking. HOTS are critical and creative thinking skills. Wan Mazwati Wan Yusoff (2018: 50-51) details core critical thinking skills including analysis, evaluation, interpretation, inference explanation, and self-regulation. Meanwhile, core creative thinking skills include fluency, flexibility, elaboration, and originality. HOTS, which is applied in this teaching material, is based on the revised Bloom Taxonomy, in the form of analyzing, evaluating, and creating.

HOTS obtained by SMK students through practicing solving issues from the industrial world indicate a life skill. This is confirmed by Suranto AW (2019: 13) that communication skills are related to overall performance and life skills. Some of the required communication skills include: (1) an active listener, (2) an effective presenter, (3) a quick thinker, and (4) a win-win negotiator. Through learning problem solving from DU-DI, which contains HOTS in the teaching material, it can lead SMK students to the meaningfulness of learning contained in the teaching material, which condition the reality of negotiating to absorb the needs of the job market. Life skills through negotiation skills are strengthened by Andayani (2016: 749), that all the characteristics that cause the function of hard skills owned by soft skills can determine the direction of using hard skills. If someone has it well, then the knowledge and skills that they master can bring prosperity and comfort to the owner and the environment.

Sulaiman and Shahrill (2015) state that life skills as a broad knowledge are indispensable as an essential asset for living independently. Meanwhile, Supriatna (2007: 4) explains that life 
skills are defined as skills possessed by a person to face life's problems. Both of these opinions assume that adequate life skills of SMK students can provide opportunities for success in living life in the context of the DU-DI. The specifications for this teaching material emphasize problem solving made by DU-DI partners in the product marketing. The issue of the DU-DI partner is a tool to stimulate the negotiation skills of SMK students. This state of the art includes the latest developments in learning negotiation texts that align the needs of DUDI. Zahroh (2014) in her research states that integrating negotiation skills in learning at SMK will provide students with skills and mental readiness and be responsive towards changing conditions to be faced in the world of work. This product considers the effectiveness and targets of direct learning. This research is also a form of a contribution to developing a textbook that integrates soft skills negotiating with DUDI needs based on problem solving. The compilation of teaching material product content that collaborates with DU-DI in the business field of product sales is a novelty part that can develop SMK students' skills.

Specifically, this study aims to produce negotiation text for the teaching material product oriented to HOTS in the context of life skills in DU-DI for SMK and describe its feasibility, including the level of validity, practicality, attractiveness, and effectiveness of the product. This goal is in line with the National Research Master Plan (RIRN) as well as the adjustment and development of vocational school curriculum by the Ministry of Education and Culture with demand-driven, which optimizes the DUDI while advancing vocational education. The teaching material product is packaged in electronic format through the school website, which is in line with the 2013 curriculum, which moves dynamically following the digital era. The compilation of content on teaching material products is by collaborating with DU-DI in the business field of selling products aligned with the areas of expertise in SMK.

\section{MATERIALS AND METHODS}

This study used Research and Development (R \& D) from Borg and Gall, in which it is research to produce a certain product and test the effectiveness of the product (Sugiyono, 2014: 407). The stages applied in this research include five of the ten stages stated by Borg and Gall with the following development flow. (1) Research \& information collector for preliminary studies. (2) Planning includes product design and its development process. (3) Developing preliminary form of product with activities to prepare learning materials, compile lesson plans, develop the product with a predetermined learning approach, conduct validation tests on linguists and language learning experts, collect interview data, fill out questionnaires, and notes suggestions and comments, and revise the development of product validation tests. (4) Preliminary field testing with a practicality test on Indonesian language teachers and an attractiveness test on SMK students. (5) Main product revision, including revising the main product as a whole, processing interview data, filling out questionnaires, and notes on suggestions and comments. Besides, the dissemination stage was done by providing the product to the target SMK and informing the Indonesian Language Teachers Working Group (MGMP) of SMK.

This study involved SMK with marketing expertise. The subject of product testing (validation) included three groups: (1) experts in developing teaching materials in the field of language and learning, (2) the initial field trial group for assessing the textbook practicality was carried out on two Indonesian language teachers; and (3) the attractiveness test was carried out on $10^{\text {th }}$ grade students. This model follows the context of the implementation of the latest Indonesian curriculum, which gives teachers authority as a participatory team. The data collection instruments consisted of a questionnaire, interview guidelines, and test sheets. The questionnaire was intended for testing experts (a linguist and a language learning expert), Indonesian language teachers, and small groups of vocational students. Interview guidelines were used for verbally clarifying written suggestions and comments that were not yet clear to the researchers.

This research data analysis used simple qualitative and quantitative techniques. Qualitative data in the form of verbal data were obtained from interviews and written notes in the form of written comments on the questionnaire. Quantita- 
Journal of Development Research, 4 (2), November 2020, Pages 97-105

Tabel 1. Calculation of Data Analysis

\begin{tabular}{|c|c|c|c|}
\hline \multicolumn{2}{|c|}{ Test Results } & \multirow{2}{*}{ Follow up } \\
\hline Category & Percentage & Qualification & \\
\hline 4 & $86 \%-100 \%$ & Very Feasible & Implementation \\
\hline 3 & $76 \%-85 \%$ & Feasible & Implementation \\
\hline 2 & $56 \%-75 \%$ & Feasible Enough & Revision \\
\hline 1 & $<55 \%$ & Not Feasible & Revision \\
\hline
\end{tabular}

tive techniques were used to analyze quantitative data obtained from a textbook product assessment questionnaire. Data obtained from a questionnaire about the textbook's feasibility, including the level of validity, practicality, attractiveness, and effectiveness of the textbook product, were analyzed using simple quantitative techniques by calculating the percentage of answers of each question item. The data processing of the validated questionnaire was analyzed with the formula for data processing per item $P=\frac{x}{x i} \times 100 \%$ and data processing for the whole item $P=\frac{\Sigma x}{\Sigma x i} \times 100 \%$. Table 1 shown interpretation of the results of data analysis, the following interpretations are used.

\section{RESULT AND DISCUSSION}

Basic Competencies (KD) and Competency Achievement Indicators (IPK) that are developed into the textbook product on negotiation texts in the context of life skills are arranged through the distribution of KD and IPK as follows.

The process of developing textbooks of negotiation text oriented to Higher Order Thinking Skills (HOTS) with the context of life skills in DU-DI for SMK conducted in this study was adapted from the model of Borg and Gall covering five stages of the existing ten stages, namely research \& information collector, planning, developing the preliminary form of product, preliminary field testing, and main product revision. The following is the data obtained from a series of development processes that had been carried out.

The planning stage that had been done is a continuation of the need analysis stage in the preliminary study. This stage aims to focus the textbook regarding Negotiation Text in the Context of Life Skills on fulfilling the need to achieve learning objectives. The next stage is the development of

Table 2. Distribution of KD and IPK of Indonesian Language Subject in Class X

\begin{tabular}{|c|c|c|c|}
\hline \multicolumn{2}{|r|}{ Basic Competencies } & \multicolumn{2}{|r|}{ Competency Achievement Indicators } \\
\hline 3.10 & $\begin{array}{l}\text { Evaluating proposal, offer, and agreement } \\
\text { in negotiation texts orally and written }\end{array}$ & $\begin{array}{l}2 . \\
3 .\end{array}$ & $\begin{array}{l}\text { Formulating the characteristics of the negotia- } \\
\text { tion text } \\
\text { Explaining how to deliver a proposal and offer. } \\
\text { Explaining the terms of approval (agreement) }\end{array}$ \\
\hline 4.10 & $\begin{array}{l}\text { Delivering proposal, offer, agreement, and } \\
\text { closing in the negotiation text orally or } \\
\text { written }\end{array}$ & 1. & $\begin{array}{l}\text { Analyzing the determining factors for making } \\
\text { negotiation successful } \\
\text { Using the right reasons to make a proposal and } \\
\text { offer in oral negotiation } \\
\text { Explaining the presentation patterns of the ne- } \\
\text { gotiation text }\end{array}$ \\
\hline 3.11 & $\begin{array}{l}\text { Analyzing the content, structure } \\
\text { (orientation, proposal, offer, agreement, } \\
\text { closing) and the linguistic of the negotia- } \\
\text { tion text }\end{array}$ & $\begin{array}{l}1 . \\
2 .\end{array}$ & $\begin{array}{l}\text { Deciding structures of the negotiation text } \\
\text { Mentioning elements of the offering and order- } \\
\text { ing goods letter. } \\
\text { Identifying pairs negotiation in the negotiation } \\
\text { text } \\
\text { Identifying persuasive sentences in the negotia- } \\
\text { tion text }\end{array}$ \\
\hline 4.11 & $\begin{array}{l}\text { Constructing negotiation texts by empha- } \\
\text { sizing the content, structure (orientation, } \\
\text { proposal, offer, agreement, closing), and } \\
\text { the linguistic aspect. }\end{array}$ & 1 . & $\begin{array}{l}\text { Creating oral negotiation texts in the form of } \\
\text { dialogue } \\
\text { Creating oral negotiation texts in the form of } \\
\text { narrative }\end{array}$ \\
\hline
\end{tabular}

Copyright (C) 2020, JDR, E ISSN 2579-9347 P ISSN 2579-9290 
Journal of Development Research, 4 (2), November 2020, Pages 97-105

Table 3. Expert Validation Results

\begin{tabular}{|c|l|c|c|c|c|}
\hline No & \multicolumn{1}{|c|}{ Component } & $\begin{array}{c}\% \text { Expert } \\
1\end{array}$ & $\begin{array}{c}\% \\
\text { Expert 2 }\end{array}$ & $\begin{array}{c}\text { Average Per- } \\
\text { centage }\end{array}$ & Criteria \\
\hline 1. & Contents Components & $83.75 \%$ & $80.56 \%$ & $82.15 \%$ & Feasible - Implementation \\
\hline 2. & $\begin{array}{l}\text { Systematic Presentation } \\
\text { Components }\end{array}$ & $100 \%$ & $100 \%$ & $100 \%$ & Very Feasible - Implementation \\
\hline 3. & $\begin{array}{l}\text { Language Variety Compo- } \\
\text { nents }\end{array}$ & $91.67 \%$ & $100 \%$ & $95.83 \%$ & Very Feasible - Implementation \\
\hline 4. & Display Components & $86.1 \%$ & $83.3 \%$ & $84.7 \%$ & Feasible - Implementation \\
\hline \multicolumn{4}{|r|}{ Overall Average } & $90.67 \%$ & Very Feasible - Implementation \\
\hline
\end{tabular}

Table 4. Trial Results on Indonesian Language Teachers of SMK

\begin{tabular}{|c|l|c|c|}
\hline No & \multicolumn{1}{|c|}{ Component } & Percentage & Criteria \\
\hline 1. & Contents Components & $93.75 \% \%$ & Very Feasible - Implementation \\
\hline 2. & Systematic Presentation Components & $87.5 \%$ & Very Feasible - Implementation \\
\hline 3. & Language Variety Components & $93.58 \%$ & Very Feasible - Implementation \\
\hline 4. & Display Components & $84.37 \%$ & Feasible - Implementation \\
\hline \multicolumn{2}{|l|}{ Overall Average } & $89.8 \%$ & Very Feasible - Implementation \\
\hline
\end{tabular}

the initial product. These initial product development activities included preparing learning materials, compiling RPP, and developing the textbook product regarding negotiation text in the context of life skills. Developing products was done by using the learning approach that had been decided. Then, the researchers performed validation tests on a linguist and a language learning expert. Moreover, data collection was obtained through interviews, questionnaires, advice notes, and comments. The initial product development is intended to collect data used in the field trial process of the initial stage by revising the initial product based on experts' advice before conducting the initial field trial. After expert validation by the linguist and language learning expert was carried out, the next stage was preliminary field testing. The initial phase of field trials conducted was a practicality test done by Indonesian language teachers of SMK in Kediri, East Java. Revision of the attractiveness test was done based on the teacher's advice before conducting the attractiveness test of the textbook in the students. Next, the researchers conducted the attractiveness test of the product in a small group of students The feasibility of the teaching material in the form of a textbook regarding negotiation texts oriented to Higher Order Thinking Skills (HOTS) with the context of life skills in the business and industrial world for students of SMK in tenth-grader was conducted with four stages of tests including two stages of expert validation and two stages of field tests. Two expert validation stages were (1) a linguist test and (2) a language learning expert test. The two stages of field tests were (1) product trial conducted by teachers and (2) product trial conducted to students. Expert validation on textbook products was conducted by two experts, a linguist and a language learning expert. Two Indonesian teachers and students of tenthgrader in SMK conducted the textbook product trial. This teaching material's feasibility was derived from the expert validation results of a linguist and a language learning expert. Based on the results of media validation by experts, the data obtained is as Table 3.

The data, which had been obtained and analyzed from the validation of language learning experts, was then conducted in trials on Indonesian language teachers of SMK in Kediri, East Java. Shown in Table 4. The data, which had been obtained and analyzed from the validation of language learning experts, was then conducted in trials on students of SMK in Kediri, East Java 
Journal of Development Research, 4 (2), November 2020, Pages 97-105

Table 5. Trial Results on Students of SMK

\begin{tabular}{|c|l|c|c|}
\hline No & \multicolumn{1}{|c|}{ Component } & Percentage & Criteria \\
\hline 1. & Contents Components & $83.3 \%$ & Feasible - Implementation \\
\hline 2. & $\begin{array}{l}\text { Systematic Presentation } \\
\text { Components }\end{array}$ & $100 \%$ & Very Feasible - Implementation \\
\hline 3. & $\begin{array}{l}\text { Language Variety Com- } \\
\text { ponents }\end{array}$ & $100 \%$ & Very Feasible - Implementation \\
\hline 4. & Display Components & $91,67 \%$ & Very Feasible - Implementation \\
\hline Overall Average & $93,74 \%$ & Implementation \\
\hline
\end{tabular}

shown in Table 5.

In the data analysis, the researchers described the detailed results of the material's feasibility tests involving a linguist, a language learning expert, and Indonesian language teachers of SMK. Feasibility tests on a linguist and a language learning expert aim to assess the teaching material's validity level before it is used in the learning process in the real situation. Feasibility tests on teachers aim to assess the practicality level of the teacher's ease in using the teaching material in the classroom. The description of the data analysis of the feasibility test is described as follows.

The first component is the content. The result of expert validation of the component is $83.75 \%$. This percentage includes the appropriateness of KI and KD with IPK, development, accuracy, depth, and completeness of materials, as well as learning sources and assessment. Based on the material's accuracy, the orientation of Higher Order Thinking Skills (HOTS) is appropriate with the wording and content of the negotiation text based on the learning principles that can support HOTS improvement. This is in line with Dolan \& Collins's statement (in Sulisworo: 2019) that there are some things to encourage the improvement of HOTS, including teaching the concept of a concept, saying and showing, moving from concrete to abstract and back, teaching steps of the concept of learning. The content of the negotiation text on the product was structured by providing a concept and steps of a concept of structure and linguistic of the negotiation text. Also, abstract to concrete learning and concrete to abstract learning were included in this textbook product by presenting examples and exercises of negotiating abstractly and concretely. The content component also contains a description of the material described in this textbook based on vocational school stu- dents' development.

Validation of content components by a language learning expert shows a percentage of $80.56 \%$. This percentage is oriented at the learning stage. Sinambela (2013) states that three important aspects should be considered in learning, namely affective, psychomotor, and cognitive. The steps of each learning should not be separated from all three aspects. Besides, aspects of attitude or affective aspects should be included in the transformation of substance or teaching materials so that students "know why". The psychomotor aspect should be involved in the transformation of substance or teaching material so that students "know how". The cognitive aspect should be included in the transformation of substance or teaching materials so that students "know what."

The percentage of trials done by the Indonesian teacher of the tenth-grader students of SMK regarding the content component is $93.75 \%$. This is emphasized on the effective and efficient of the textbook product when it is applied in learning. Setyosari (2014) states that effective learning cannot be separated from the quality of learning because the quality of the learning outcomes depends on the learning process's effectiveness or occurred in the learning process itself. Muhson (2010) also states that the most effective learning is learning at the base of the cone, which is directly involved with purposeful learning experiences. The two opinions align with the development of the textbook product of negotiation text in the context of life skills, which can give students the opportunity to obtain the concept of negotiation text and the steps of learning activities that can be replicated or followed so that it can facilitate students in achieving learning objectives.

The second component is a systematic presentation. The percentage result of validation done by a linguist and a language learning expert 
is $100 \%$. This component relates to the main component of the textbook product of the negotiation text in the context of life skills that had been compiled sequentially and based on the learning steps. Muslich (2010:301-303) proposes the completeness of the presentation into three, namely (1) preliminaries (preface, instructions for use, table of contents, and list of symbols), (2) texts matter (images or illustrations, references, presentation of each chapter, and summary), and (3) postliminaries (bibliography, subject index, glossary, and instructions for use). Furthermore, the percentage result of the trial done by Indonesian language teachers of the tenth-grader is $87.5 \%$. The thing that must be considered in this component is that the product needs to be adjusted with the order of IPK.

The third component is the variety of languages. The validation component by a linguist is $91.67 \%$ and the language learning expert is $100 \%$. Moreover, the percentage result of trials done by Indonesian language teachers of the tenth-grader is $95.58 \%$. The assessment of this component includes theories, instructions, exercises, and examples presented using a formal, communicative, and logical language. It is in line with the results of Utami's (2018) research which found that the communicative and interactive language is encompassed in every learning activity. This teaching material also uses command sentences that aim to invite students to be active in learning activities. Besides, each instruction presented in each subchapter is also dominated by question sentences and command sentences.

The fourth component is the display. The percentage result of the validation of the display component done by the linguist is $86.1 \%$, validation of the component done by the language learning expert is $83.3 \%$, and the trial done by the Indonesian teachers of SMK is $84.37 \%$. According to Utami's (2020) statement, the attractiveness of the teaching material, one of them can be seen from the graphic or the appearance of the teaching material. The textbook display regarding the negotiation text in the context of life skills was adjusted to students' interests, especially students of SMK.

\section{CONCLUSION}

The results of the study showed that there are four components of assessment, namely content, systematic presentation, language variety, and display. The first is the content component validated by the linguist that the percentage is $83.75 \%$, the percentage of the language learning expert is $80.56 \%$, and the percentage of field trials on Indonesian teachers of SMK is $93.75 \%$. The second is the component of the systemic presentation validated by the linguist and the language learning expert that shows a percentage of $100 \%$, and field trials on Indonesian teachers of SMK that obtain a percentage of $87.5 \%$. The third is the language variety component validated by the linguist that shows a percentage of $91.67 \%$, the language learning experts that obtain $100 \%$, and field trial of Indonesian teacher of SMK that obtain $93.58 \%$. The fourth is the language variety component validated by the linguist that the percentage is $86.1 \%$, the percentage of language learning expert is $83.3 \%$, and the percentage of field trials of Indonesian language teachers of SMK is $84.37 \%$. Overall, an average percentage based on the data showed that the textbook product of negotiation text in the context of life skills was categorized as the very feasible textbook that can be implemented in the learning regarding negotiation text in SMK. Thus, this product can be disseminated to SMK for the learning materials of Indonesian subjects.

\section{SUGGESTION}

Based on the results of the research, there are suggestions for future research. (1) The scope of real experience from the business and the industrial world can be expanded by establishing cooperation with the business and the industrial world, which is often used as a place of Industrial Work Practice (prakerin) by students of SMK. (2) For further research, the researchers should not only develop a product with five stages, but also implement the R \& D stages of the Borg \& Gall model entirely on ten development stages.

\section{REFERENCES}

Andayani, Endah. (2016). Analisis Praktik Kerja Industri terhadap Penguasaan Skill Siswa dalam Menghadapi Dunia Kerja di SMK NU Bululawang Malang. Jurnal Inspirasi Pendidikan. Universitas Kanjurhan Malang: Volume 6 Nomor 1. 
Anderson, L.W., and Krathwohl, D.R. (2001). A Taxonomy of Learning, Teaching, and Assessing: A Revision of Bloom's Taxonomy of Educational Objectives. New York: Longman.

Brookhart, S. M. (2010). How to Assess Higher Order Thinking Skills in Your Classroom. Alexandria: ASCD

Aw, Suranto , Pratiwi Wahyu Widiarti, \& Chatia Hastasari. (2019). Evaluasi Program Pelatihan Keterampilan Dasar Komunikasi bagi Siswa di SMKN 1 Godean Sleman. Jurnal Efisiensi Kajian Ilmu Administrasi Edisi Februari 2019, Vol. XVI No. 1, ISSN $1412-$ 1131, e-ISSN 2528-5750, Hal. 11-21.

Funke, Joachim, Andreas Fischer, and Daniel V. Holt. (2018). Competencies for Complexity: Problem Solving in the Twenty-First Century. Department of Psychology, Heidelberg University, Heidelberg, Germany: Springer International Publishing $\mathrm{AG}$ 201841 E. Care et al. (eds.), DOI 10.1007/978-3-319-65368-6 3.

Hendra, Suwardana. (2017). Revolusi Industri 4. 0 Berbasis Revolusi Mental. Jati Unik: Vol.1, No.2, Hal. 102-110.

Kemendikbud. (2013). Buku Guru: Bahasa Indonesia Ekspresi Diri dan Akademik untuk Kelas X. Jakarta: Kementerian Pendidikan dan Kebudayaan.

Komariah, Kokom. (2011). Penerapan Metode Pembelajaran Problem Solving Model Polya untuk Meningkatkan Kemampuan Memecahkan Masalah Bagi Siswa Kelas Ix J di SMPN 3 Cimahi. Prosiding Seminar Nasional Penelitian, Pendidikan dan Penerapan MIPA, Fakultas MIPA, Universitas Negeri Yogyakarta, 14 Mei 2011.

Mahsun. (2014). Teks dalam Pembelajaran Bahasa Indonesia Kurikulum 2013. Jakarta: Rajawali Pers.

Muhson, Ali. (2010). Pengembangan Media Pembelajaran Berbasis Teknologi Informasi. Dalam Jurnal Pendidikan Akuntansi Indonesia, Volume VIII, Nomor 2, Juli 2010, hlm. 1-10.

Muslich, M. (2010). Text Book Writing. Jogjakarta: Ar-ruzz Media.
Ophélie Dubois. (2019). Is negotiation the best alternative solution to resolve conflicts in the food industry?. PM World Journal: Vol. VIII, Issue VI - July 2019.

Sabalala, Nahari. (2014). Artikel: Mengabstraksi Teks Negosiasi. Tersedia: http:// naharisabalala.blogspot.com /2014/05/ mengabstraksi teks negosiasi.html. Diakses pada tanggal 20 November 2014.

Setyosari, Punaji. (2014). Menciptakan Pembelajaran yang Efektif dan Berkualitas. Dalam Jurnal Inovasi dan Teknologi Pembelajaran, Volume 1, Nomor 1, Oktober 2014, hlm. 21.

Sinambela, Pardomuan Nauli Josip Mario. (2013). Kurikulum 2013 dan Implementasinya dalam Pembelajaran. Dalam Generasi Kampus UNIMED, Volume 6, Nomor 2, September 2013, hlm. 20.

Sriyanto, S., Indri Murniawaty, Tri Na'imah. (2019). Negotiation Competencies Based on Assertiveness and Self Efficacy for Vocational High School Students. Dinamika Pendidikan- http:// journal.unnes.ac.id/nju/index.php/dp: 14 (1) (2019) 116-126.

Sulaiman, N. D., \& Shahrill, M. (2015). Engaging Collaborative Learning to Develop Students' SkiIls of the 21st Century. Mediterranean Journal of Social Sciences, 6 (4), 544.

Sulisworo, Dwi. (2019). Teori Dan Praktek Mobile Collaborative Learning. Yogyakarta: CV Markumi.

Sugiyono. (2014). Metode Penelitian Pendidikan: Pendekatan Kuantitatif, Kualitatif, dan $R \& D$. Bandung: Alfabeta.

Utami, Sri. (2018). Pengembangan Bahan Ajar Teks Anekdot Untuk Sekolah Menengah Kejuruan Kelas X. Dalam Briliant: Jurnal Riset dan Konseptual, Volume 3, Nomor 1, Februari 2018, hlm. 9.

Utami, Sri. (2020). Pengembangan Bahan Ajar Teks Cerita Panji Berbasis Content Language Integrated Learning (CLIL) untuk SMK. Dalam Briliant: Jurnal Riset dan Konseptual, Volume 5, Nomor 1, Februari 2020, hlm. 34.

Yusoff, Wan Mazwati Wan dan Shamilati Che 
Journal of Development Research, 4 (2), November 2020, Pages 97-105

Seman. 2018. Teachers' Knowledge of Higher Order Thinking and Questioning Skills: A Case Study at a Primary School in Terengganu, Malaysia. International Kournal of Academic Research in Progressive Education \& Development: http://dx.doi.org/10.6007/

IJARPED/v7-i2/4120 DOI: 10.6007/

IJARPED/v7-i2/4120. 